\title{
PERANCANGAN APLIKASI SURAT KETERANGAN TANDA LAPOR KEHILANGAN PADA KANTOR KEPOLISIAN RESOR SUMBAWA BERBASIS ANDROID
}

\author{
*Shinta Esabella dan A. Rahman \\ Program Studi Teknik Informatika, Fakultas Teknologi Informatika, Universitas Teknologi Sumbawa \\ * Corresponding author. E-mail: sesabella@gmail.com,rahman.fti.uts@gmail.com
}

\begin{abstract}
The purpose of this writing is to identify the results of the analysis and the design of Application of Loss Signs Certificate (SKTLK) built by using Waterfall method, it is chosen because this method is a conventional and systematic model, sequential in building application software. The research begins with the stage of analyzing, designing, coding and testing. Although in the testing phase this application is merely able to run within the Localhost network, nevertheless it has provided the expected output as a basic concept for the presence of more complex and integrated application development, where the results of this study are expected to be one of the suggestions that contributes to the decision of the Highest Policy Holder on The Sumbawa Police Force to expand various applications within the Sumbawa Police Resort as one of the steps to improve the public service to the community.
\end{abstract}

Keywords: Aplication, Waterfall, Localhost

\section{PENDAHULUAN}

Teknologi Informasi berkembang pesat dalam berbagai aktivitas kehidupan dan memberikan kesempatan untuk dapat dimanfaatkan secara tepat dan efektif. Tidak hanya untuk kemudahan memperoleh dan memberikan informasi, saat ini pemanfaatan teknologi informasi telah banyak memberi bantuan dalam proses penyelesaian masalah dengan metode efisiensi waktu.

Kantor Kepolisian Resor Sumbawa merupakan salah satu instansi negara yang memiliki pelayanan kepada masyarakat, dalam proses pelayanan kepada masyarakat instansi ini menginginkan adanya efisiensi waktu. Sampai saat ini proses pelayanan seperti pembuatan Surat Keterangan Tanda Lapor Kehilangan (SKTLK) dari Kantor Kepolisian Resor Sumbawa kepada masyarakat masih dilakukan dengan cara masyarakat langsung datang ke Kantor Kepolisian Resor Sumbawa yang beralamat di Jalan Hasanuddin 105 Sumbawa Besar. Meninjau proses yang mengharuskan masyarakat melakukan proses daftar tunggu pembuatan Surat Keterangan Kehilangan membuat Kepala Unit II Sentra Pelayanan Kepolisian Terpadu, Romy O. Munir, SH menyampaikan keiinginannya akan hadirnya sebuah aplikasi yang memudahkan setiap pelayanan dari Kepolisian Resor Sumbawa kepada masyarakat [1].

Berdasarkan masalah di atas, peneliti merancang sebuah Aplikasi Surat Keterangan Tanda Lapor Kehilangan pada Kantor Kepolisian Resor Sumbawa berbasis android. Aplikasi ini menggunakan metode penelitian Waterfall, dimana aplikasi yang dibangun terbatas pada masalah masyarakat yang ingin membuat laporan kehilangan Kartu Tanda Penduduk (KTP). Masyarakat sebagai Pelapor dapat membuat SKTLK dengan mengisi data sesuai yang diminta dari Kepolisian melalui media smartphone yang berbasis android, kemudian pihak Kepolisian dapat mengeluarkan SKTLK sesuai dengan laporan yang telah diterima.

Diharapkan dengan hadirnya aplikasi ini dapat menjadi konsep dasar aplikasi yang dapat menjadi pertimbangan untuk membantu pengambilan keputusan Pemegang Kebijakan Tertinggi pada Kepolisian Resor Sumbawa sehingga dapat mengembangkan berbagai aplikasi di lingkungan Kepolisian Resor Sumbawa sebagai salah satu langkah peningkatan proses pelayanan kepada masyarakat dengan cara yang efektif dan efisien.

\section{METODOLOGI}


Metode perancangan dalam penelitian ini menggunakan metode Waterfall yang merupakan model klasik yang bersifat sistematis, berurutan dalam membangun sebuah software [2]. Adapun langkah dalam metode ini [3] yang digunakan untuk membangun Aplikasi SKTLK pada Kantor Kepolisian Resor Sumbawa adalah sebagai berikut:

\section{Analysis}

Pada tahap ini, merupakan proses analisa kebutuhan aplikas yang akan dibangun. Peneliti mengumpulkan data-data sebagai bahan perancangan aplikasi. Pengumpulan data yang dilakukan peneliti dalam penelitian ini adalah dengan menggunakan teknik wawancara dan teknik observasi [4] pada Unit II Sentra Pelayanan Kepolisian Terpadu dalam bagian pembuatan Surat Keterangan Tanda Lapor Kehilangan pada Kantor Kepolisian Resor Sumbawa.

\section{Design}

Proses desain adalah proses multi langkah yang berfokus pada empat atribut, yaitu: struktur data, arsitektur perangkat lunak, representasi interface, dan detail prosedural. Proses desain menterjemahkan hasil analisis ke dalam representasi perangkat lunak. Adapun dalam penelitian ini, pada tahap design menggunakan perancangan tersetruktur [5] dengan menggunakan Diagram Konteks, Data Flow Diagram, Entity Relationship Diagram dan Perancangan Database serta Tampilan Antar Muka untuk memudahkan dalam proses pengkodean.

\section{Code}

Pada tahap ini design diterjemahkan ke dalam program perangkat lunak. Pada tahap pengimplementasian ke dalam kode program akan bergantung pada hasil desain perangkat lunak pada tahap sebelumnya.

\section{Test}

Setelah pengkodean, diterlanjutkan dengan pengujian terhadap aplikasi SKTLK yang telah dibuat. Pengujian dilakukan dengan terlebih dahulu mengimplementasikan aplikasi sehingga dapat diketahui kesesuaian hasil output dari aplikasi dengan kebutuhan yang telah dirancang pada tahap analisis.

\section{HASIL DAN PEMBAHASAN}

Dengan menggunkan metode Waterfall dalam penelitian ini, maka proses yang dilakukan dalam membangun Aplikasi Surat Keterangan Tanda Lapor Kehilangahan (SKTLK) pada Kantor Kepolisian Resor Sumbawa adalah sebagai berikut:

\section{Analisis}

Merupakan tahap awal untuk mendapatkan data dan informasi, dimana pada tahap ini peneliti melakukan kumunikasi dengan pihak pimpinan Sentra Pelayanan Kepolisian Terpadu, masyarakat sebagai pelapor atau pemakai dan petugas pada bagian penerbitan Surat Keterangan Tanda Lapor Kehilangahan (SKTLK) pada Kantor Kepolisian Resor Sumbawa. Berikut adalah hasil analisis kebutuhan dalam penelitian ini:

\section{Kebutuhan Data}


Adapun Kebutuhan Data yang didapatkan berupa data dan informasi yang bersumber antara lain (Tabel 1):

Tabel 1. Kebutuhan Data

\begin{tabular}{|l|l|}
\hline \multicolumn{1}{|c|}{ Sumber } & \multicolumn{2}{|c|}{ Data dan Informasi } \\
\hline $\begin{array}{l}\text { Kepala Unit II } \\
\text { Sentra } \\
\text { Pelayanan } \\
\text { Kepolisian } \\
\text { Terpadu (SPKT) } \\
\text { Kepolisian Resor } \\
\text { Sumbawa }\end{array}$ & $\begin{array}{l}\text { Pelayananan } \\
\text { Kepolisian kepada } \\
\text { masyarakat berbasis } \\
\text { Teknologi Informasi } \\
\text { (aplikasi dengan user } \\
\text { friendly) }\end{array}$ \\
\hline $\begin{array}{l}\text { Petugas } \\
\text { Pelayanan } \\
\text { penerbitan } \\
\text { SKTLK }\end{array}$ & $\begin{array}{l}\text { Format Formulir } \\
\text { permohonan } \\
\text { Penerbitan SKTLK }\end{array}$ \\
\hline $\begin{array}{l}\text { Masyarakat } \\
\text { (sample) }\end{array}$ & $\begin{array}{l}\text { Kemudahan dalam } \\
\text { proses pengurusan } \\
\text { SKTLK }\end{array}$ \\
\hline
\end{tabular}

2. Kebutuhan Perangkat Keras

Tabel 2 memperlihatkan Kebutuhan Perangkat Keras dalam penelitian ini.

3. Kebutuhan Perangkat Lunak

Kebutuhan Perangkat Lunak dalam penelitian ini ditunjukkan pada Tabel 3.

Tabel 2. Kebutuhan Perangkat Keras

\begin{tabular}{|l|l|}
\hline \multicolumn{1}{|c|}{ Perangkat Keras } & \multicolumn{1}{c|}{ Keterangan } \\
\hline Motherboard & ASUS P5 \\
\hline Processor & Pentium 4D 3 GHz \\
\hline RAM & DDR RAM 2 GB \\
\hline Hard Disk & Seagate SATA80GB \\
\hline Optical Drive & ASUS DVD-RW \\
\hline Monitor & Philips 17" Flat \\
\hline
\end{tabular}




\begin{tabular}{|l|l|}
\hline LAN Card & OnBoard 1 Gbps \\
\hline Cassing & Simcool Big Tower \\
\hline
\end{tabular}

Tabel 3. Kebutuhan Perangkat Lunak

\begin{tabular}{|l|l|}
\hline \multicolumn{1}{|c|}{ Perangkat Lunak } & \multicolumn{1}{|c|}{ Keterangan } \\
\hline Operating System & $\begin{array}{l}\text { Windows 2010 } \\
\text { Profesional }\end{array}$ \\
\hline DBMS & MySQL Versi 5.5 \\
\hline Web Server & XAMPP Versi 3 \\
\hline Editor & Sublime Text \\
\hline Jumework & $\begin{array}{l}\text { (User Interface - } \\
\text { Design) } \\
\text { PhoneGap } \\
\text { (Compile) }\end{array}$ \\
\hline Scripting Language & PHP \\
\hline Other Language & JavaScript \\
\hline LAN Work Station & Local Host \\
\hline
\end{tabular}

\section{Design}

Selanjutnya dilakukan proses perancangan, dimana bertujuan untuk memberikan gambaran apa yang seharusnya dikerjakan dan bagaimana tampilannya. Tahap ini membantu dalam menspesifikasikan kebutuhan sistem serta mendefinisikan arsitektur sistem secara keseluruhan. Dalam tahap ini digunakan perancangan terstruktur untuk memudahkan dalam proses membangun Aplikasi SKTLK.

\section{Konteks Diagram}

Diagram konteks adalah diagram yang terdiri dari suatu proses dan menggambarkan ruang lingkup suatu sistem. Diagram konteks merupakan level tertinggi dari DFD (Data Flow Diagram) yang menggambarkan seluruh input ke sistem atau output dari sistem. Berikut adalah gambar Gambar 1 memperlihatkan Konteks Diagram dalam sistem Aplikasi SKTLK pada penelitian ini:

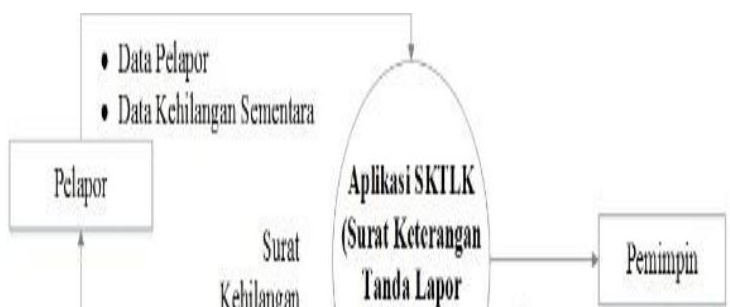


Dari Gambar 1 di atas, aplikasi SKTLK menerima Data Pelapor dari masyarakat dan kemudian data yang diolah diserahkan kepada pelapor yang meminta data SKTLK serta adanya laporan dari aplikasi SKTLK ke pada pimpinan.

\section{Data Flow Diagram (DFD)}

Diagram Arus Data (Data Flow Diagram atau DFD) adalah diagram yang menggunakan notasi-notasi untuk menggambarkan arus data sistem. Gambar DFD Level 0 pada Aplikasi SKTLK dapat dilihat pada Gambar 2.

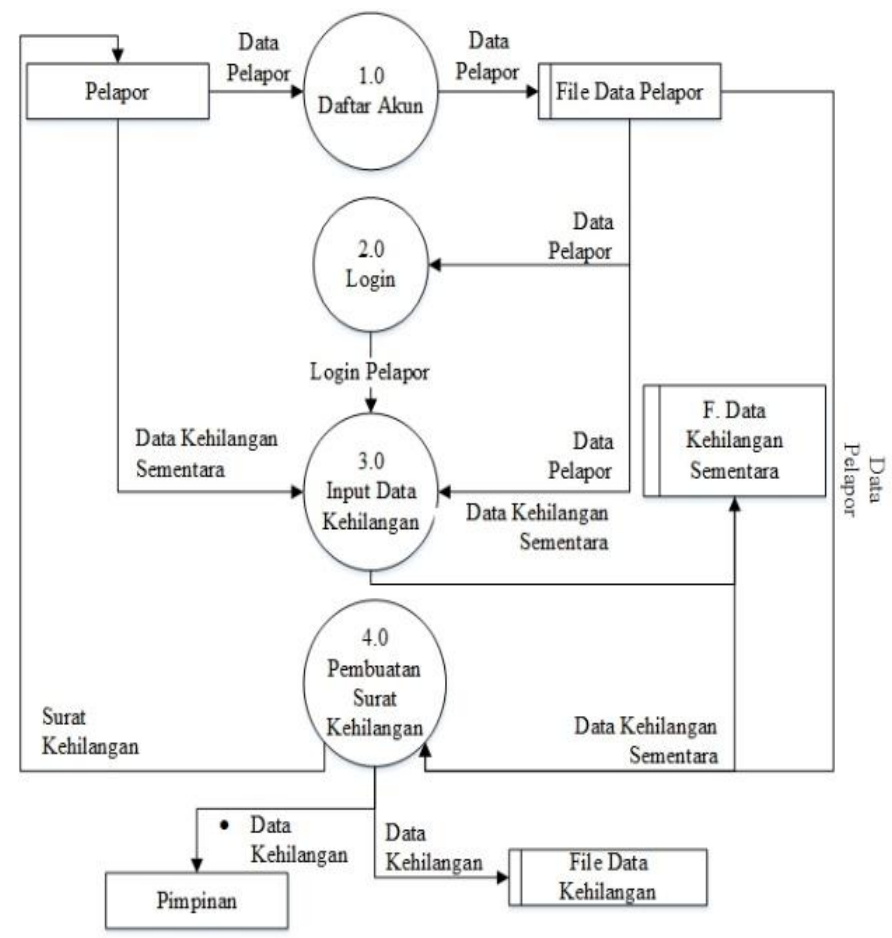

Gambar 2. DFD Level 0

\section{ERD (Entity Relationship Diagram)}

Entity-Relationship yang berisi komponen-komponen Himpunan Entitas dan Himpunan Relasi yang masing-masing dilengkapi dengan atribut-atribut yang mempersentasikan seluruh entitas yang digunakan. Entity Relationship Diagram dalam aplikasi SKTLK ditunjukkan pada Gambar 3. 


\section{Perancangan Basis Data}

Merupakan proses menciptakan perancangan untuk basis data yang akan mendukung operasi dan tujuan aplikasi. Dalam penelitian ini basis data yang digunakan ada 4 file, yaitu file data pelapor (Tabel 4), file data kehilangan sementara (Tabel 5), file data kehilangan (Tabel 6), dan file admin (Tabel 7).

Gambar 3. Entity Relationship Diagram

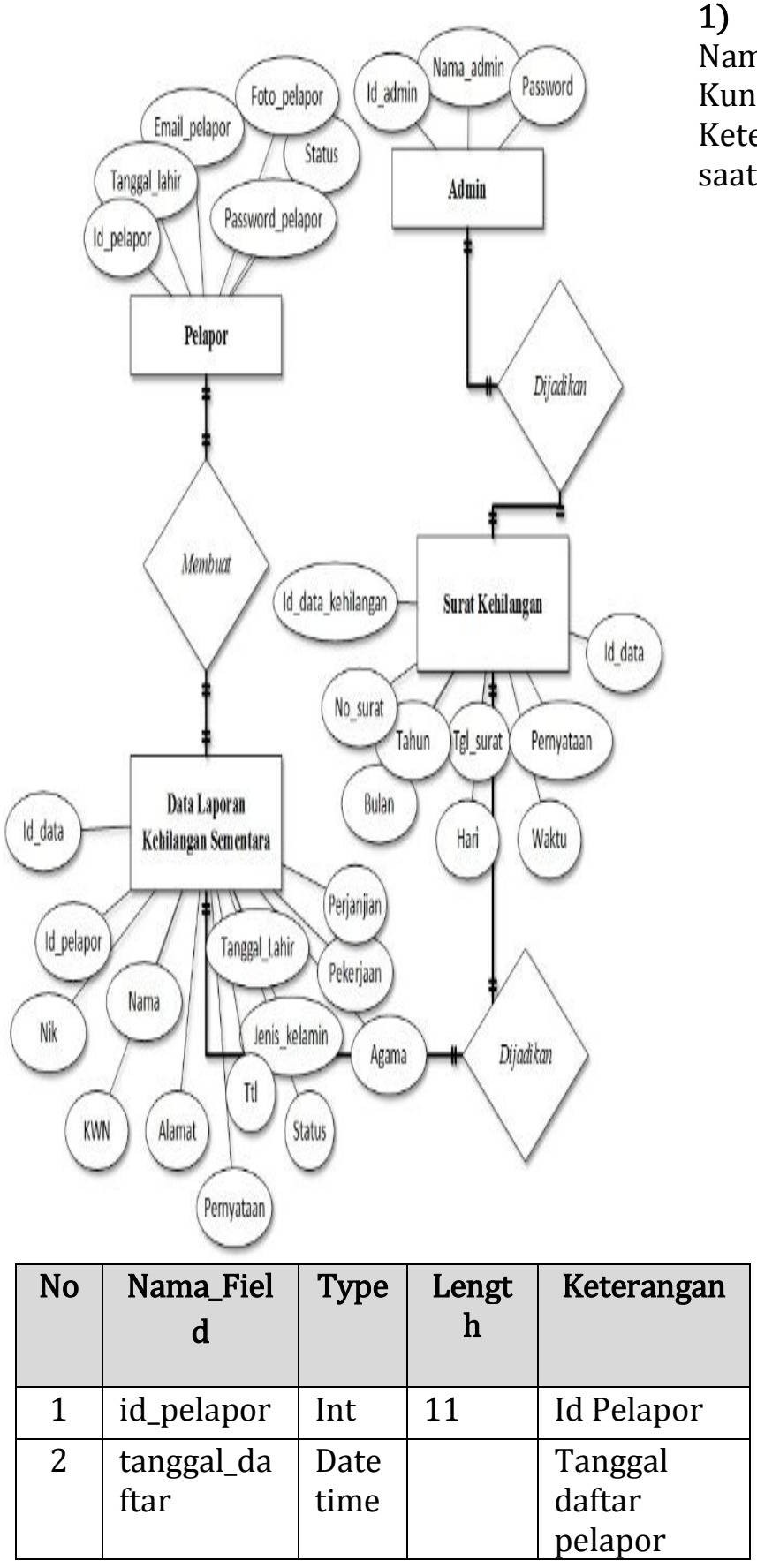

1) File Data Pelapor

Nama File : file_data_pelapor

Kunci File : id_pelapor

Keterangan : Digunakan untuk menyimpan data saat pelapor mendaftar

Tabel 4. File Data Pelapor 


\begin{tabular}{|c|l|l|l|l|}
\hline 3 & $\begin{array}{l}\text { email_pela } \\
\text { por }\end{array}$ & $\begin{array}{l}\text { varc } \\
\text { har }\end{array}$ & 50 & $\begin{array}{l}\text { Email } \\
\text { pelapor }\end{array}$ \\
\hline 4 & $\begin{array}{l}\text { password_ } \\
\text { pelapor }\end{array}$ & $\begin{array}{l}\text { Varc } \\
\text { har }\end{array}$ & 30 & $\begin{array}{l}\text { Password } \\
\text { Pelapor }\end{array}$ \\
\hline 5 & $\begin{array}{l}\text { Foto_pelap } \\
\text { or }\end{array}$ & Text & $\begin{array}{l}\text { Foto profil } \\
\text { pelapor }\end{array}$ \\
\hline 6 & Status & Int & 2 & $\begin{array}{l}\text { Status } \\
\text { pelapor }\end{array}$ \\
\hline
\end{tabular}

\section{2) File Data Kehilangan Sementara}

Nama File : file_data_kehilangan_sementara

Kunci File : id_data

Keterangan: Digunakan untuk menyimpan data laporan dari pelapor yang diisi berdasarkan KTP yang hilang.

Tabel 5 memperlihatkan data kehilangan sementara.

Tabel 5. File Data Kehilangan Sementara

\begin{tabular}{|c|c|c|c|c|}
\hline No & $\begin{array}{c}\text { Nama_Fi } \\
\text { eld }\end{array}$ & Type & $\begin{array}{c}\text { Lengt } \\
\mathrm{h}\end{array}$ & $\begin{array}{c}\text { Keteranga } \\
\text { n }\end{array}$ \\
\hline 1 & id_data & Int & 11 & $\begin{array}{l}\text { ID Data } \\
\text { sebagai } \\
\text { primary } \\
\text { key }\end{array}$ \\
\hline 2 & $\begin{array}{l}\text { id_pelap } \\
\text { or }\end{array}$ & Int & 11 & $\begin{array}{l}\text { ID Pleapor } \\
\text { sebagai } \\
\text { foreign }\end{array}$ \\
\hline 3 & tgl_data & $\begin{array}{l}\text { Dateti } \\
\text { me }\end{array}$ & & $\begin{array}{l}\text { Tanggal } \\
\text { Data } \\
\text { diinput }\end{array}$ \\
\hline 4 & Nik & Int & 16 & NIK \\
\hline 5 & Nama & $\begin{array}{l}\text { Varcha } \\
\text { r }\end{array}$ & 50 & $\begin{array}{l}\text { Nama } \\
\text { Pelapor }\end{array}$ \\
\hline 6 & Ttl & $\begin{array}{l}\text { Varcha } \\
\text { r }\end{array}$ & 50 & $\begin{array}{l}\text { Tempat } \\
\text { tggl lahir }\end{array}$ \\
\hline 7 & $\begin{array}{l}\text { jenis_kel } \\
\text { amin }\end{array}$ & $\begin{array}{l}\text { Varcha } \\
\text { r }\end{array}$ & 15 & $\begin{array}{l}\text { Jenis } \\
\text { kelamin } \\
\text { pelapor }\end{array}$ \\
\hline 8 & Alamat & Text & & $\begin{array}{l}\text { Alamat } \\
\text { pelapor }\end{array}$ \\
\hline 9 & Agama & $\begin{array}{l}\text { Varcha } \\
\mathrm{r}\end{array}$ & 10 & $\begin{array}{l}\text { Agama } \\
\text { pelapor }\end{array}$ \\
\hline 10 & Status & $\begin{array}{l}\text { Varcha } \\
\text { r }\end{array}$ & 20 & $\begin{array}{l}\text { Status } \\
\text { pelapor }\end{array}$ \\
\hline 11 & $\begin{array}{l}\text { Pekerjaa } \\
\mathrm{n}\end{array}$ & $\begin{array}{l}\text { varcha } \\
\mathrm{r}\end{array}$ & 100 & $\begin{array}{l}\text { Pekerjaan } \\
\text { pelapor }\end{array}$ \\
\hline
\end{tabular}




\begin{tabular}{|c|l|l|l|l|}
\hline 12 & Kwn & $\begin{array}{l}\text { varcha } \\
\text { r }\end{array}$ & 3 & $\begin{array}{l}\text { Kewargan } \\
\text { egraan } \\
\text { pelapor }\end{array}$ \\
\hline 13 & $\begin{array}{l}\text { Pernyata } \\
\text { an }\end{array}$ & Text & $\begin{array}{l}\text { Pernyataa } \\
\text { n dari } \\
\text { pelapor }\end{array}$ \\
\hline
\end{tabular}

\section{3) File Data Kehilangan}

Nama File : file_data_kehilangan

Kunci File : id_data_kehilangan

Keterangan : Digunakan untuk menyimpan data yang diinput oleh admin dalam proses pembuatan surat, akan digabungkan dengan table file data kehilangan sementara yang memiliki data kehilangan dari pelapor yang sesuai dengan KTP.

Tabel 6. File Data Kehilangan

\begin{tabular}{|c|c|c|c|c|}
\hline No & Nama_Field & Type & $\begin{array}{c}\text { Lengt } \\
\mathrm{h}\end{array}$ & $\begin{array}{c}\text { Keteran } \\
\text { gan }\end{array}$ \\
\hline 1 & $\begin{array}{l}\text { id_data_kehi } \\
\text { langan }\end{array}$ & int & 11 & $\begin{array}{l}\text { sebagai } \\
\text { primary } \\
\text { key }\end{array}$ \\
\hline 2 & id_data & int & 11 & $\begin{array}{l}\text { Sebagai } \\
\text { foreign } \\
\text { key }\end{array}$ \\
\hline 3 & no_surat & int & 11 & $\begin{array}{l}\text { Untuk } \\
\text { nomor } \\
\text { surat }\end{array}$ \\
\hline 4 & Bulan & $\begin{array}{l}\text { varc } \\
\text { har }\end{array}$ & 5 & $\begin{array}{l}\text { Untuk } \\
\text { bulan } \\
\text { dibuatn } \\
\text { ya surat }\end{array}$ \\
\hline 5 & Tahun & int & 4 & $\begin{array}{l}\text { Tahun } \\
\text { surat }\end{array}$ \\
\hline & tgl_surat & $\begin{array}{l}\text { varc } \\
\text { har }\end{array}$ & 11 & $\begin{array}{l}\text { Untuk } \\
\text { tanggal } \\
\text { surat }\end{array}$ \\
\hline 6 & Hari & $\begin{array}{l}\text { varc } \\
\text { har }\end{array}$ & 50 & $\begin{array}{l}\text { Hari } \\
\text { saat } \\
\text { surat } \\
\text { dibuat }\end{array}$ \\
\hline 7 & Waktu & $\begin{array}{l}\text { varc } \\
\text { har }\end{array}$ & 10 & $\begin{array}{l}\text { Waktu } \\
\text { saat } \\
\text { surat } \\
\text { dibuat }\end{array}$ \\
\hline 8 & $\begin{array}{l}\text { Penyataan_o } \\
\text { lah }\end{array}$ & text & & $\begin{array}{l}\text { Untuk } \\
\text { pernyat } \\
\text { aan } \\
\text { laporan } \\
\text { yang }\end{array}$ \\
\hline
\end{tabular}




\begin{tabular}{|l|l|l|l|}
\hline & & & $\begin{array}{l}\text { telah } \\
\text { diolah }\end{array}$ \\
\hline
\end{tabular}

4) Admin

Nama File : admin

Kunci File : id_admin

Keterangan : Data untuk admin

Tabel 7. File Admin

\begin{tabular}{|c|l|l|l|l|}
\hline No & Nama_Field & Type & Length & Keterangan \\
\hline 1 & id_admin & Int & 5 & $\begin{array}{l}\text { sebagai } \\
\text { primary } \\
\text { key }\end{array}$ \\
\hline 2 & nama_admin & Varchar & 50 & $\begin{array}{l}\text { Untuk } \\
\text { admin } \\
\text { login }\end{array}$ \\
\hline 3 & Password & varchar & 20 & $\begin{array}{l}\text { Untuk } \\
\text { keamanan } \\
\text { admin }\end{array}$ \\
\hline
\end{tabular}

\section{Perancangan Antar Muka}

Perancangan antarmuka merupakan proses merancang interface yang efektif untuk aplikasi perangkat lunak yang akan dibangun. Dalam penelitian ini terdapat dua bagian yaitu tampilan sisi server atau pada petugas admin Penerbitan SKTLK (Gambar 4 dan 5) dan pada sisi client atau masyarakat sebagai pelapor (Gambar 6 dan 7).

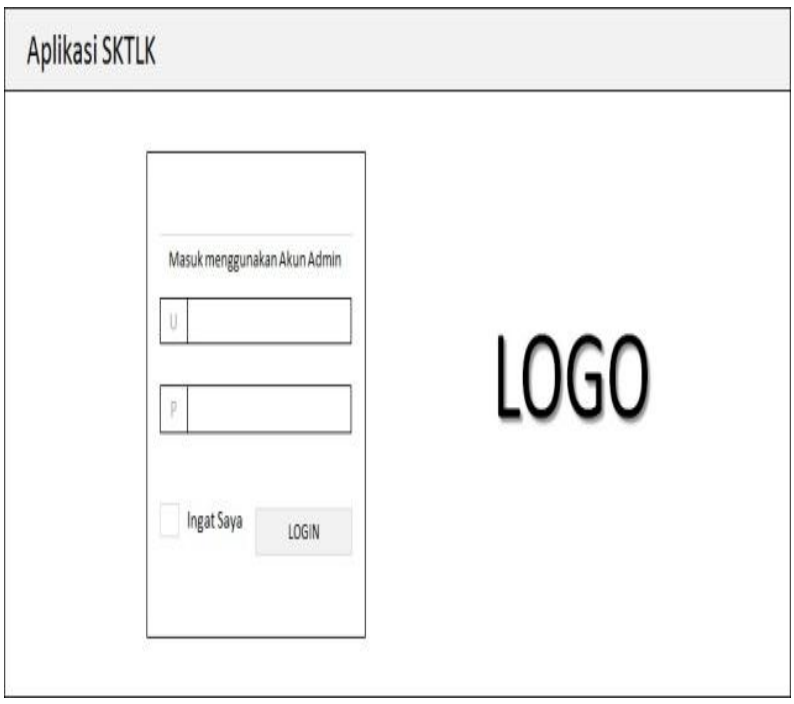

Gambar 4. Tampilan Login Admin

Dari Gambar 4 pada sisi tampilan Login Admin, agar dapat masuk ke dalam aplikasi SKTLK admin harus memiliki hak akses sesuai dengan wewenang yang diberikan oleh Kepala Unit II Sentra Pelayanan Kepolisian Terpadu (SPKT) Kepolisian Resor Sumbawa. 


\begin{tabular}{|c|c|c|}
\hline \multicolumn{2}{|c|}{ Aplikasi SKTLK } & I Namaddrin $\mathrm{V}$ \\
\hline Dashboard & Home > Oashboard & \\
\hline \multirow{7}{*}{ Pengaduan } & & \\
\hline & 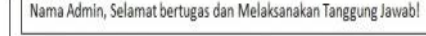 & \\
\hline & & \\
\hline & & \\
\hline & & \\
\hline & & \\
\hline & & \\
\hline
\end{tabular}

Gambar 5. Rancangan Halaman Utama Admin

Dari Gambar 5 tampak sisi tampilan Halaman Utama Admin, admin dapat melihat menu yang disediakan yaitu pengadaan penerbitan SKTLK.

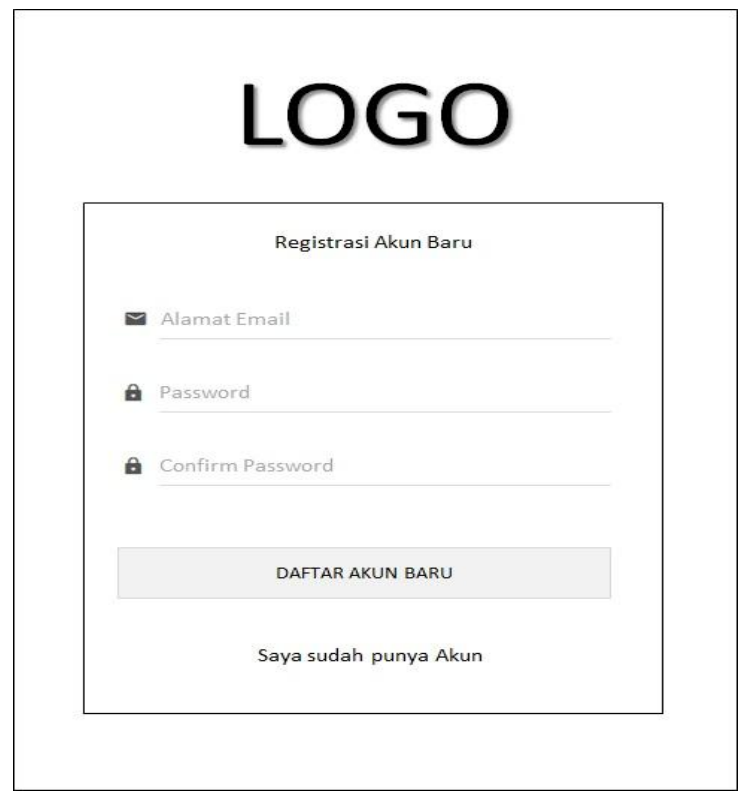

Gambar 6. Rancangan Tampilan Daftar User

Tampilan Daftar User diperlihatkan oleh Gambar 6. Pelapor wajib menjadi user di dalam aplikasi dengan cara membuat akun yang telah disediakan oleh aplikasi SKTLK. Dengan membuat akun terlebih dahulu diharapkan data yang masuk ke dalam aplikasi adalah data yang valid. 


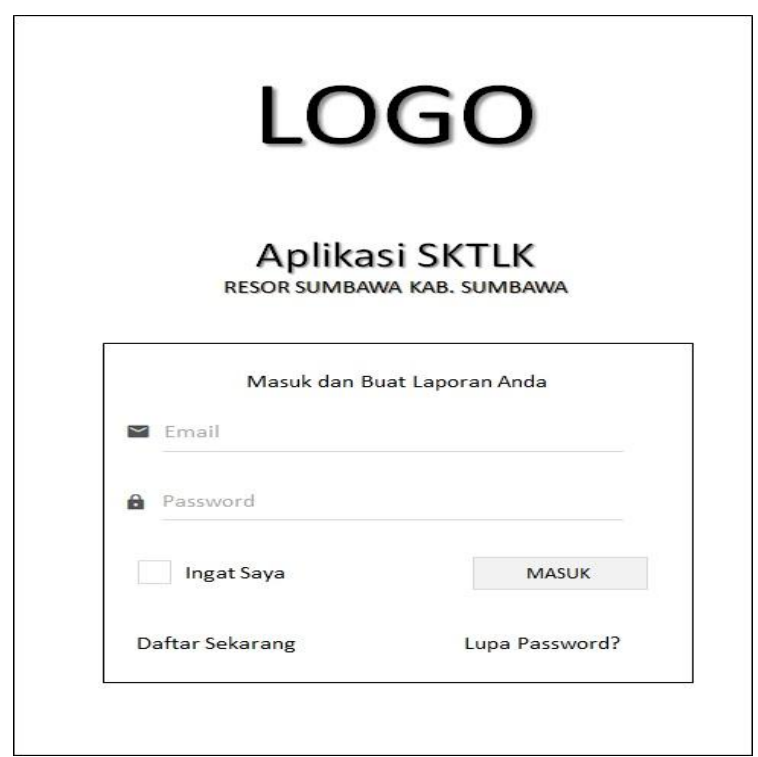

Gambar 7. Rancangan Tampilan Login User

Gambar 7 menunjukkan tampilan Login User. Pelapor yang telah menjadi user di dalam aplikasi dapat masuk ke dalam aplikasi dan melakukan input data pengaduan kehilangan.

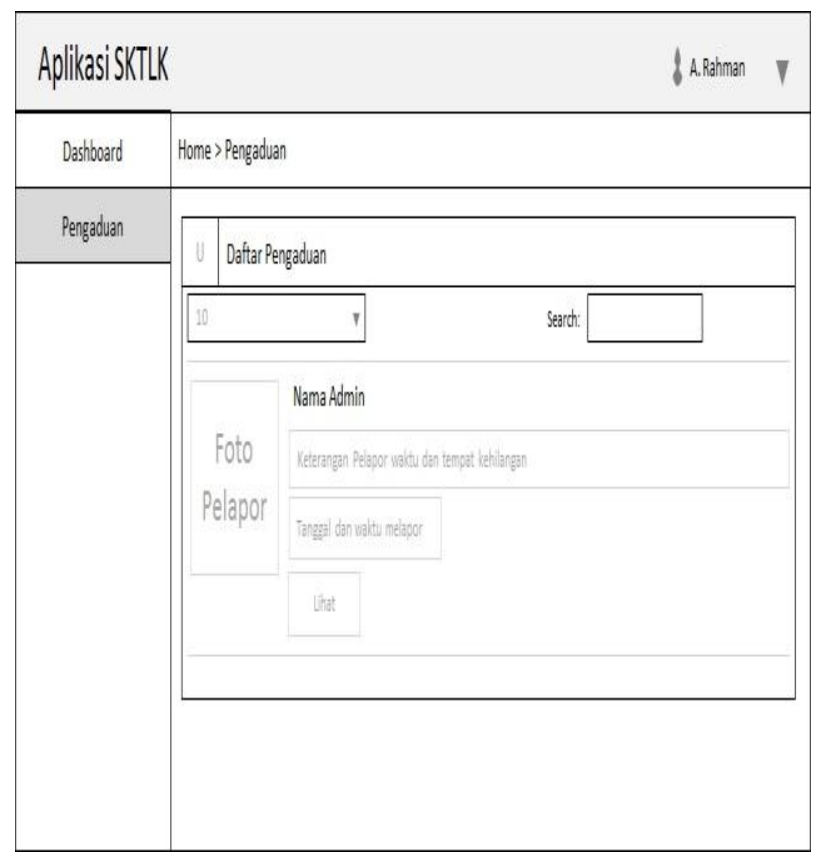

Gambar 8. Rancangan Tampilan Pengaduan User

Dari gambar diatas pada sisi tampilan Pengaduan User, pelapor dapat memasukkan data dan keterangan kehilangan ke dalam aplikasi. 
Kemudian, rancangan pengaduan user (pelapor) diperlihatkan pada Gambar 8. Berdasarkan Gambar 8 tersebut, pelapor dapat memasukkan data dan keterangan kehilangan dalam aplikasi. Gambar 9 menunjukkan rancangan tampilan SKTLK yang akan didapatkan pelapor. Rancangan tersebut dibuat seperti format asli yang diberikan oleh bagian penerbitan SKTLK pada Kantor Kepolisian Resor Sumbawa.

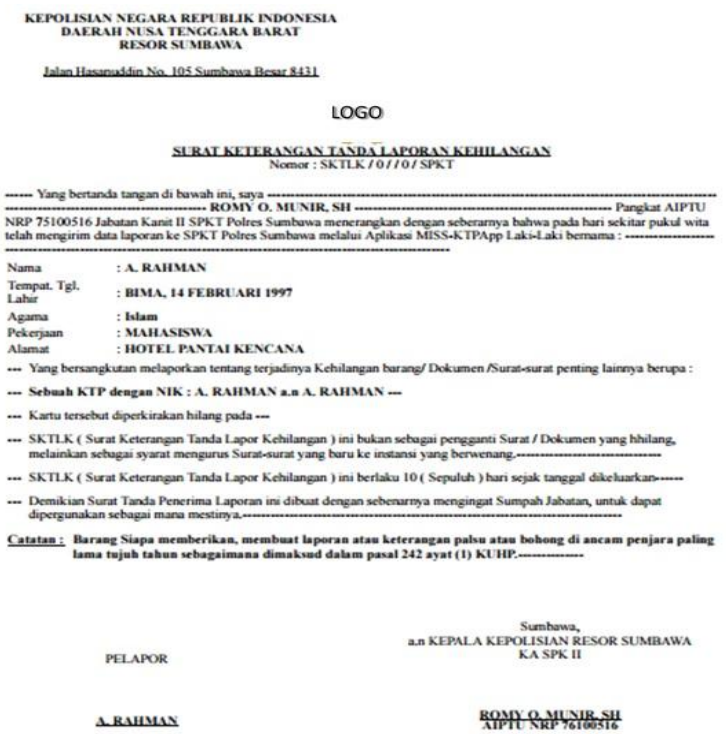

Gambar 9. Rancangan Tampilan SKTLK

\section{Code}

Pada tahap ini desain diterjemahkan ke dalam program perangkat lunak. Dimana proses pengkodean di awali dengan membangun Database pada basisdata MySQL dengan menggunkan XAMPP. Adapun editor untuk membantu pengkodean dangan PHP (Hypertext Preprocessor) dan Java Script menggunakan Sublime Text.

\section{Test}

Setelah pengkodean, dilakukan pengujian terhadap aplikasi SKTLK yang telah dibuat. Pengujian dilakukan dengan terlebih dahulu melakukan proses mengimplementasian aplikasi pada halaman login admin (Gambar 10). 


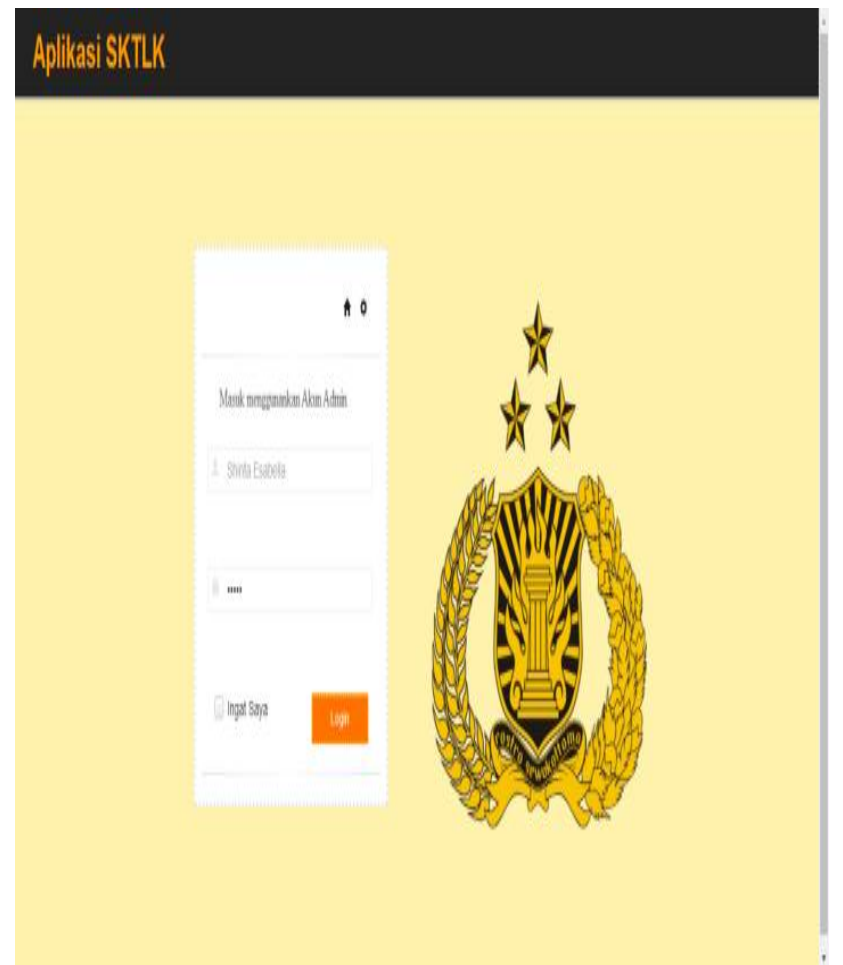

Gambar 10. Halaman Login Admin

Pada halaman Login Admin (Gambar 10), admin harus memasukan terlebih dahulu username dan password untuk dapat masuk ke dalam aplikasi SKTLK, hal tersebut sebagai bentuk keamanan penggunaan aplikasi.

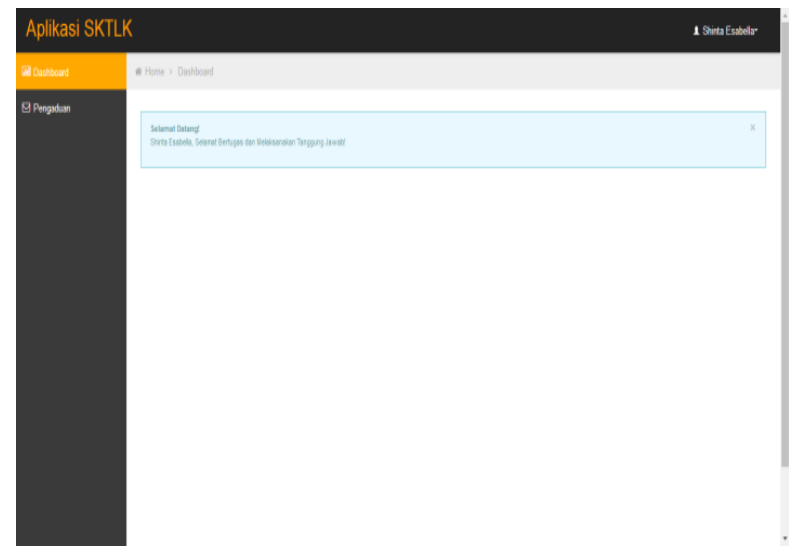

Gambar 11. Halaman Utama Admin

Berdasarkan Gambar 11, admin dapat melihat menu yang disediakan yaitu pengadaan penerbitan SKTLK. Dimana, admin sebagai petugas yang memiliki wewenang untuk menerbitkan SKTLK, berhak untuk memberikan atau tidak surat kehilangan tersebut kepada pelapor. 


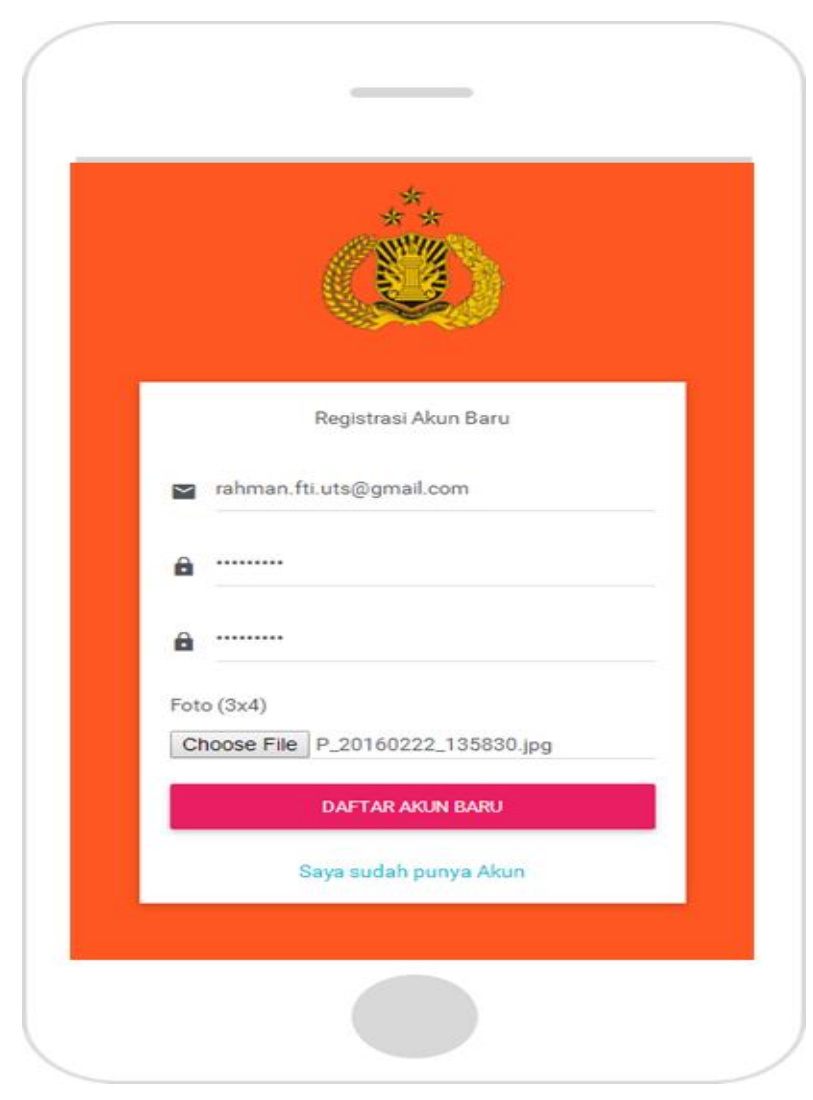

Gambar 12. Halaman Daftar User

Pada sisi halaman Daftar User (Gambar 12), pelapor wajib menjadi user di dalam aplikasi dengan cara membuat akun dengan mengisi alamat email, password dan melampirkan foto pada form yang telah disediakan oleh aplikasi SKTLK. Dengan membuat akun terlebih dahulu diharapkan data yang masuk ke dalam aplikasi adalah data yang valid. 


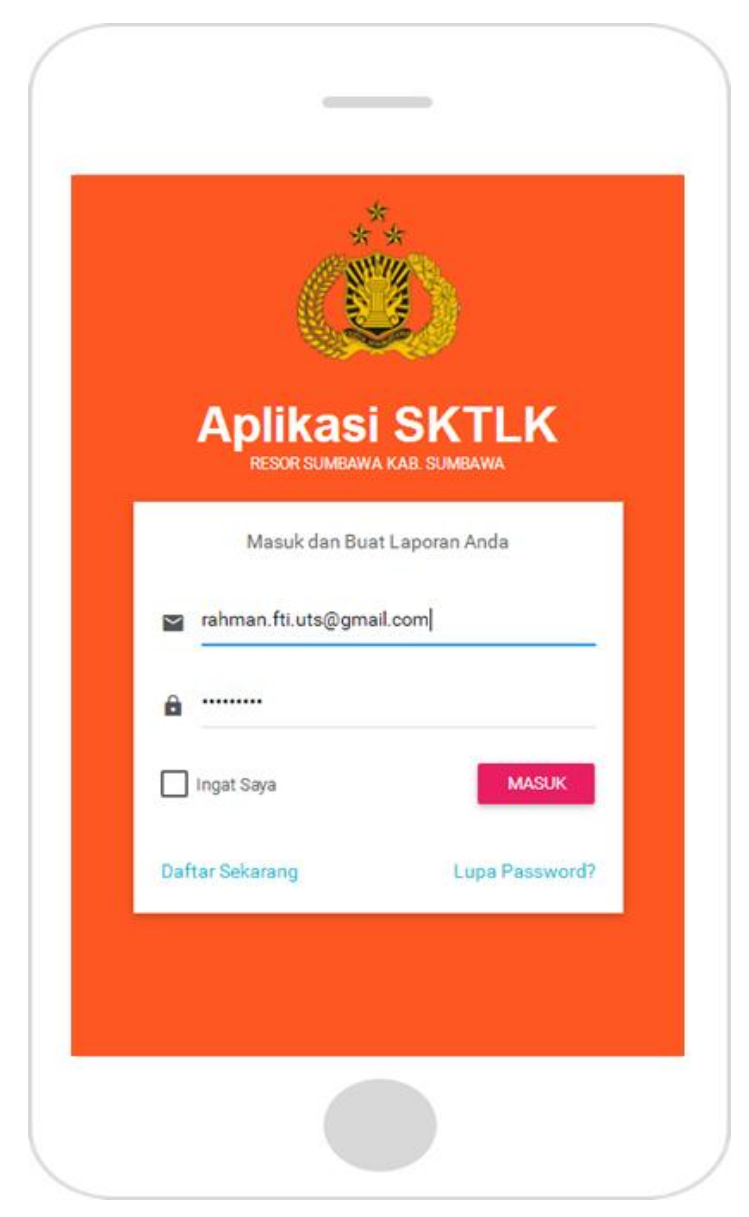

Gambar 13. Halaman Login User

Gambar 13 menunjukkan halaman Login User. Pelapor yang telah menjadi user di dalam aplikasi dapat masuk ke dalam aplikasi dan melakukan input data pengaduan kehilangan.

Selanjutnya, pelapor yang telah berhasil login dan masuk ke dalam aplikasi SKTLK, dapat memasukkan data dan keterangan kehilangan ke dalam aplikasi. Adapun data yang dimasukkan pelapor adalah Nomor Induk KTP, Nama, Tempat Tanggal Lahir, Alamat, Agama, Status, Pekerjaan, Kewarganegaraan dan Keterangan Tempat Kehilangan. Adapun tampilan Halaman Pengaduan Pelapor dalam aplikasi berbasis android ditunjukkan pada Gambar 14. 


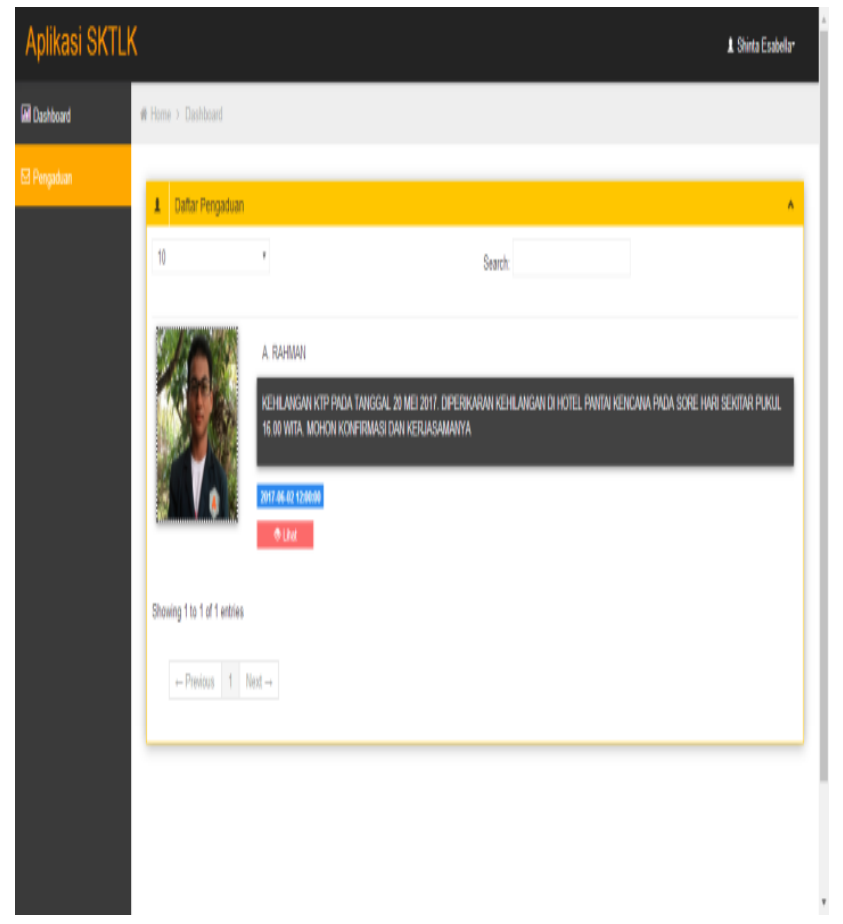

Gambar 14. Halaman Pengaduan User

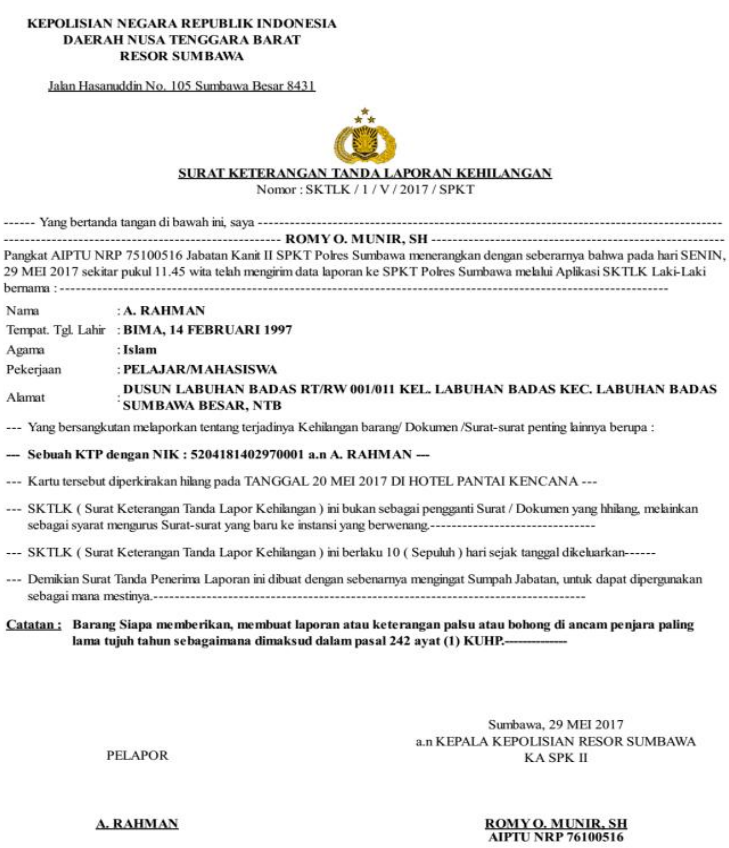

Gambar 15. Halaman SKTLK

Gambar 15 menunjukkan tampilan SKTLK sebagaimana format asli yang akan diterima pelapor setelah melakukan pelaporan melalui Aplikasi SKTL tersebut. 
Adapun proses pengujian aplikasi telah dilakukan dengan menjalankan aplikasi yang dimulai dari pelapor mendaftar untuk memiliki akun dalam Aplikasi SKTLK, kemudian masuk kedalam aplikasi dan melakukan pengaduan serta diterbitkannya oleh petugas (admin) SKTLK. Namun, proses implementasi input data dan keluaran yang dilakukan dalam penelitian ini masih berjalan dalam jaringan local host [6] menggunakn web browser yang tersedia dalam perangkat penelitian.

\section{KESIMPULAN \& SARAN}

\section{Kesimpulan}

Dengan menggunakan metode Waterfall dalam penelitian ini yang terdiri dari tahap analysis, design, coding dan testing telah menghasilkan Aplikasi SKTLK yang sesuai dengan perancangan. Meskipun aplikasi ini hanya menyajikan laporan kehilangan kartu tanda penduduk dan berjalan dalam jaringan Localhost dalam penelitian laboratorium, namun telah menunjukan hasil yang dapat dijadikan sebagai konsep dasar untuk pengembangan Aplikasi SKTLK sehingga hasil penelitian ini dapat menjadi salah satu masukkan untuk membantu Pemegang Kebijakan Tertinggi pada Kepolisian Resor Sumbawa dalam mengambil keputusan terhadap proses peengembangan aplikasi yang lebih kompleks dan terintegrasi sebagai proses pelayanan kepada masyarakat.

\section{Saran}

Adapun saran dalam penelitian ini, yakni :

1. Dapat dilakukan pengembangan dengan Halaman Pengaduan selain Kehilangan Kartu Tanda Penduduk, seperti Halaman Kehilangan Kendaran Bermotor, Perhiasan dan sebagainya.

2. Dapat dilakukan pengembangan data yang terintegrasi dengan instansi lain, seperti terintegrasi dengan database pegawai Kepolisian, database Data Penduduk pada Kantor Capil maupun pada data instansi lainnya.

3. Dapat dilakukan pendaftaran aplikasi dalam Play Store sehingga memudahkan user untuk terhubung dengan Aplikasi.

\section{DAFTAR PUSTAKA}

[1] Munir, Romy O., Wawancara 04 Mei 2017. Kepala Unit II Sentra Pelayanan Kepolisian Terpadu, Kepolisian Resor Sumbawa.

[2] Pressman, R.S. (2010), Software Engineering : a practitioner's approach, McGraw- Hill, New York, 68.

[3] Romadhoni, Eka NA dkk. 2015. Implemantasi Model Waterfall Pada Pengembangan Sistem Informasi Alumni SMKN 1 Jenengan Ponorogo. Disajikan dalam Seminar Nasional Sistem Informasi Indonesia.

[4] Rosa \& Shalahuddin. 2013. Rekayasa Perangkat Lunak. Bandung: Informatika. 
[5] Rohayati, Mita. 2014. Membangun Sistem Informasi Monitoring Data Inventory di Vio Hotel Indonesia. Jurnal Ilmiah Komputer dan Informatika. Edisi 1 Vol.1, ISSN : 20899033.

[6] Hoendarto. 2015. Perancangan Aplikasi Koperasi Simpan Pinjam. berbasis Jaringan Localhost. Jurnal InTekSis Vol 2 No 2. 